\title{
Previous Antibiotic Use and Its Influence on Antifungal Susceptibility of Candida Strains
}

\author{
Candida Türlerinin Antifungal Duyarılığında Önceki Antibiyotik Kullanımının Önemi
}

\author{
Rukiye Ada Bender', Șeyda Çalıșkan², Reyhan Aslancan³ ${ }^{3}$ Așkı Ellibeș Kaya ${ }^{4}$, Alper Bașbuğ4, Eray Çalıșkan ${ }^{5}$ \\ ${ }^{I}$ Department of Obstetrics and Gynecology, Biruni University School of Medicine, İstanbul; ${ }^{2}$ Necati Çelik Gölcük Public Hospital, İzmit; \\ ${ }^{3}$ Bahçęehir University School of Medicine, İstanbul; ${ }^{4}$ Department of Obstetrics and Gynecology, Düzce University School of Medicine, Düzce; \\ ${ }^{5}$ Department of Obstetrics and Gynecology, Bahçeşehir University School of Medicine, Istanbul, Turkey
}

\begin{abstract}
Aim: Antifungal drug resistance of Candida strains is a cause of recurrent or persistent vulvovaginal candidiasis (VVC). In order to prevent patient discomfort and to diminish the treatment cost of the disease, it is essential to identify the causative strain, determine the drug resistance status, and understand the mechanism of resistance.

Material and Method: Vaginal discharge specimens were collected from 300 patients. Sixty-five Candida albicans and thirtyfive non-albicans species were identified. The susceptibility to voriconazole, fluconazole, and amphotericin-B was examined. Previous antibiotic use and its correlation with the antifungal drug resistance were studied.
\end{abstract}

Results: Fluconazole, voriconazole and amphotericin-B susceptibilities of Candida albicans strains were 92.3\%, 86.2\%, and $100 \%$ respectively. The non-albicans group's susceptibilities to these antifungals were $45.7 \%, 22.9 \%$, and $85.7 \%$ respectively ( $p=0.00$ for all). After nitroimidazole use, $92.8 \%$ of infections were caused by Candida albicans, and $7.2 \%$ of them non-albicans strains ( $p=0.01)$. All the infections occurred after macrolide use was non-albicans infections (100\%). There were no detected candida albicans infections ( $p=0.01)$.

Conclusion: Since resistance to voriconazole, fluconazole, and amphotericin- $B$ was more frequent in the non-albicans group, physicians should suspect from non-albicans strains for treatmentresistant VVC cases. Previous antibiotic use have not increased the amphotericin $B$, fluconazole and voriconazole resistance of both candida albicans and non-albicans strains. Recurrent infections which have no response to amphotericin $B$, fluconazole or voriconazole treatment may be due to a different mechanism other than antifungal resistance of Candida species. The decreased amount of lactobacilli in vaginal flora might be the reason for recurrent VVC.

Key words: vulvovaginal candidiasis; antifungal drug resistance; candidiasis management

Rukive Ada Bender, Department of Obstetrics and Gynecology, Biruni University School of Medicine, İstanbul, Turkey, Tel.05059104499Email.r.adabender@gmail.com Geliş Taribi: 27.11.2018 • Kabul Taribi: 12.01.2019
ÖZET

Amaç: Candida sușlarının antifungal ilaç direnci, tekrarlayan veya inatçı vulvovajinal kandidiyazın (VVC) bir nedenidir. Hastanın rahatsızığını ve tekrarlayan VVC'nin ekonomik maliyetini önlemek için, nedensel sușu belirlemek, ilaç direnci durumunu belirlemek ve direnç mekanizmasını anlamak önemlidir.

Materyal ve Metot: Vajinal akıntı örnekleri 300 hastadan toplanmıș, 65 Candida albicans ve 35 non albicans türü tespit edilmiș, vorikonazol, flukonazol ve amfoterisin B'ye duyarlıık araștırımıștır. Önceki antibiyotik kullanımı ve sușların antifungal ilaç direnci ile ilișkisi araștırılmıștır.

Bulgular: Candida albicans sușlarının flukonazol, vorikonazol ve amfoterisin B duyarlılıları \%92,3, \%86,2 ve \%100 iken, nonalbicans grubunun bu antifungallere olan duyarlılıkları \%45,7, $\% 22,9$ ve \%85,7 idi (hepsi için $p=0,00$ ). Nitroimidazol kullanımından sonra, enfeksiyonların \%92,8'ine candida albicans, \%7,2'sinin non-albicans sușları neden olmuștur $(p=0,01)$. Makrolid kullanımından sonra ortaya çıkan tüm enfeksiyonların tamamında nonalbicans türleri enfeksiyona neden olurken (\%100) ve candida albicans nedenli enfeksiyon saptanmadı $(p=0,01)$.

Sonuç: Non-albicans grubunda vorikonazole, flukonazol ve amfoterisin B direnci daha sık olduğu için olduğu için, tedaviye dirençli VV olgularında klinisyenler non albicans sușlarından șüphelenmelidir. Önceki antibiyotik kullanımı, hem candida albicans hem de albicans olmayan sușların amfoterisin $B$, flukonazol ve vorikonazol direncini arttırmamaktadır. Amfoterisin B, flukonazol veya vorikonazol tedavisine cevap vermeyen tekrarlayan enfeksiyonlar, kandida türlerinin antifungal direncinden farklı bir mekanizmaya bağlı olabilir. Vajinal florada azalmıș laktobasil miktarı rekürren VVC'nin nedeni olabilir.

Anahtar kelimeler: vulvovajinal candidiyazis; antifungal ilaç direnci; candidiyazis tedavisi 


\section{Introduction}

Vulvovaginal candidiasis (VVC) which is characterized by vulvovaginal itching and irritation, thick vaginal discharge, edema on the vulvar region, vulvar swelling and external dysuria elucidates one-third of total vaginitis cases, and it is the second most common cause of vaginitis after bacterial vaginosis ${ }^{1,2}$. Candida albicans is the causative microorganism for approximately $90 \%$ of vaginal candidiasis, and the remaining $10 \%$ occurs as a consequence of colonization with Candida glabrata, Candida parapsilosis, or other uncommon non-albicans species ${ }^{3}$. Predisposing factors for VVC include diabetes mellitus, altered immune system function, increased estrogen levels, and antibiotic use $e^{4}$. The relationship between previous antibiotic use and VVC could be explained via bactericide effect of antibiotics on lactobacillus species in the vaginal ecosystem. Lactobacilli which produce lactic acid and maintain the acidity of the vagina $(\mathrm{pH}: 4-4.5)$ are protective bacteria against vulvovaginal infections through their ability to produce peroxidase which further stimulates vaginal epithelial cells to produce antimicrobial peptides ${ }^{5,6}$. It is revealed that Lactobacillus species are susceptible to most of the antibiotic groups such as nitroimidazoles, B lactams, macrolides, fluoroquinolones, or aminoglycosides ${ }^{7}$. Broad spectrum antibiotic use decreases the number of Lactobacillus species and increases the risk of VVC development ${ }^{8}$.

Candida vaginitis is divided into two groups named as uncomplicated and complicated based on their response to antifungal drug therapy. $80-90 \%$ of uncomplicated cases go under resolution after treatment while complicated infections which are characterized by four or more episodes of disease per year become chronic symptomatic disease or relapse rapidly after the first attack $^{9,10}$. Relapsing disease decreases the patients' quality of life, increases the cost of antifungal drug therapy for countries, and causes complications such as risk for miscarriage or newborn colonization in pregnant population $^{11,12}$. Each candida species demonstrate different levels of resistance and susceptibility to different antifungal drugs ${ }^{13}$. In order to decrease the rate of recurrent infections and provide sufficient resolution, it is essential to determine the causative candida strains and choose the antifungal drug which that species is susceptible.

In this study, the effects of previous antibiotic use on the susceptibility of Candida albicans and non-albicans species to Amphotericin B, Fluconazole and Voriconazole are investigated to establish an effective treatment for candida vaginitis.

\section{Material and Method}

In these two years of retrospective study, data was conducted at the VM Medical Park Kocaeli Hospital Department of Obstetrics and Gynecology between 2015 and 2017. The local ethical committee approved the study. An informed consent form was signed by each of the patients, and they filled a questionnaire about age, body mass index, systemic diseases, current infections, gravidity, and parity. Age spectrum of 300 Turkish women that were included in this study was between twenty and fifty-three. Vaginal discharge specimens were collected during routine gynecologic examination by patients with vulvovaginitis complaints. Specimens were incubated at the Sabouraud dextrose agar. After the identification of infectious agents, patients were divided into two groups as infected by Candida albicans and non-albicans.

Susceptibility of Candida species isolates to each antifungal agent was determined to utilize sixty-four great AST-YS07 (Biomerieux Inc, Hazelwood, MO) cards. The inoculum suspensions for VITEK 2 (Biomerieux Inc, Hazelwood, MO) were prepared in sterile saline at turbidity equal to $2 .{ }^{0}$ Mcfarland standard, as measured using a DensiCheck instrument (bioMerieux). The standardized fungal suspension was placed in a VITEK 2 cassette along with a sterile polystyrene test tube and the AST-YS07 card containing serial dilutions of each antifungal agent tested. Following loading of the cassette, dilutions of the fungal suspensions and card filling were performed automatically by the VITEK 2 microbial ID/AST test up to the system. The AST-YS07 cards were incubated at 35C for seventeen hours.

Data were analyzed in SPSS 20.0 program. In order to compare the results, it was established the $p$ values of the variants by using independent sample t-test and thi square in SPSS 20.0 program.

\section{Results}

Demographic characteristics of the study are indicated in Table 1. When age, body mass index, presence and recurrence of urinary tract infections, the existence of other infections and previous antibiotic use in last three months were considered, $p$ values demonstrate that 
there was no significant difference between Candida albicans and non-albicans groups.

Susceptibility and resistance profiles of Candida albicans and non-albicans pathogens to the antifungal drugs Fluconazole, Voriconazole, and Amphotericin $B$ were investigated, and results were indicated in Table 2. Since p values determined the significant difference between two groups $(p=0.001,0.001,0.001)$, susceptibility to fluconazole, voriconazole, and amphotericin B was greater in Candida albicans group, and resistance to these antifungal drugs was significantly higher in the non-albicans group.

Previously used antibiotics were categorized under seven groups, such as nitroimidazoles, Beta-lactams, tetracyclines, macrolides, aminoglycosides, and fluoroquinolones. Previous use of Beta-lactams, tetracyclines, aminoglycosides, and fluoroquinolones did not affect the distribution of Candida albicans and non-albicans infections $(p>0.05)$ (Table 3). However, candida albicans infections were significantly higher compared to non-albicans infection after the use of nitroimidazole antibiotics $(p=0.01)$, and non-albicans infections were significantly higher after use of macrolide group antibiotics $(p=0.01)$.
Effect of previous antibiotic use in the last three months on the susceptibility of Candida species to fluconazole, voriconazole and amphotericin B was investigated (Table 4 ). When fluconazole and voriconazole were considered, there was not any significant difference between antibiotic use present and absent groups ( $p=0.09$ and 0.44 , respectively). However, amphotericin $B$ usage eradicated all infections in patients used antibiotics in the last three months $(p=0.04)$. It suggests that previous antibiotic use does not affect the fluconazole and voriconazole resistance in Candida species.

\section{Discussion}

Antifungal drug resistance of Candida albicans and non-albicans species were discussed by some studies ${ }^{14-17}$. Fluconazole, itraconazole and amphotericin B resistance of the Candida species were searched from patients who had vaginitis symptoms; itraconazole and amphotericin B were effective against all candida strains while fluconazole was not ${ }^{17}$. Besides, it is showed that Candida albicans strains are more susceptible to fluconazole comparing to non-albicans species ${ }^{15}$. Some research suggests that antifungal drug resistance is statistically significantly

Table 1. Demographic variables of candida albicans and non albicans groups

\begin{tabular}{lccc}
\hline & Candida albicans $\mathrm{n}=65$ & Non-albicans $\mathrm{n}=35$ & $\mathrm{p}$ value \\
\hline Age & $34.48 \pm 6.43$ & $34.00 \pm 5.98$ & 0.74 \\
$\mathrm{BMI}$ & $25.86 \pm 4.18$ & $24.70 \pm 3.32$ & 0.20 \\
Urinary tract infection & $22(33.8 \%)$ & $15(42.8 \%)$ & 0.42 \\
Recurrent urinary tract infections two or more & $10(15.3 \%)$ & $8(22.8 \%)$ & 0.51 \\
Respiratory tract infections & $6(9.2 \%)$ & $4(10.3 \%)$ & 0.90 \\
Previous antibiotic use in last three months & $30(46.1 \%)$ & $12(34.2 \%)$ & 0.42 \\
\hline
\end{tabular}

BMI: body mass index.

Table 2. Fluconazole, voriconazole, and amphotericin B resistance and susceptibility status of candida albicans and non albicans groups

\begin{tabular}{|c|c|c|c|c|}
\hline & & Candida albicans $n=65$ & Non albicans $n=35$ & $p$ value \\
\hline \multirow{2}{*}{ Fluconazole } & Susceptibility $n=76$ & $60(92.3 \%)$ & $16(45.7 \%)$ & \multirow{2}{*}{0.001} \\
\hline & Resistance $\mathrm{n}=24$ & $5(7.7 \%)$ & $19(54.3 \%)$ & \\
\hline \multirow{2}{*}{ Voriconazole } & Susceptibility $n=64$ & $56(86.2 \%)$ & $8(22.9 \%)$ & \multirow{2}{*}{0.001} \\
\hline & Resistance $n=36$ & $9(13.8 \%)$ & $27(77.1 \%)$ & \\
\hline \multirow{2}{*}{ Amphotericin B } & Susceptibility $n=95$ & $65(100 \%)$ & $30(85.7 \%)$ & \multirow{2}{*}{0.001} \\
\hline & Resistance $n=5$ & $0(0.0 \%)$ & $5(14.3 \%)$ & \\
\hline
\end{tabular}


Table 3. Previous use of nitroimidazoles, Beta lactams, tetracyclines, amphenicoles, macrolides, aminoglycosides, and fluoroquinolones in candida albicans and non albicans groups

\begin{tabular}{lcccc}
\hline & Candida albicans $\mathrm{n}=65$ & Non albicans $\mathrm{n}=35$ & P value & Total \\
\hline Nitroimidazole & $13(92.8 \%)$ & $1(7.2 \%)$ & 0.01 & 14 \\
Beta lactam & $20(76.9 \%)$ & $6(23.1 \%)$ & 0.21 & 26 \\
Tetracycline & $4(100 \%)$ & $0(0 \%)$ & 0.13 & 4 \\
Macrolide & $0(0 \%)$ & $3(100 \%)$ & 0.01 & 3 \\
Aminoglycoside & $3(100 \%)$ & $0(0 \%)$ & 0.19 & 3 \\
Fluoroquinolone & $4(66.6 \%)$ & $2(33.4 \%)$ & 1 & 6 \\
Total & 44 & 12 & &
\end{tabular}

Table 4. Previous antibiotic use effects on fluconazole, voriconazole and amphotericin B susceptibility in Candida albicans and non albicans strains

\begin{tabular}{|c|c|c|c|c|}
\hline & & \multicolumn{2}{|c|}{ Previous antibiotic use in last three months } & \multirow[b]{2}{*}{$p$ value } \\
\hline & & Not present & Present & \\
\hline \multirow{2}{*}{ Fluconazole } & Susceptible & $39(51.3 \%)$ & $37(48.7 \%)$ & \multirow{2}{*}{0.09} \\
\hline & Resistant & $17(70.8 \%)$ & $7(29.2 \%)$ & \\
\hline \multirow{2}{*}{ Voriconazole } & Susceptible & $34(53.1 \%)$ & $30(46.9 \%)$ & \multirow{2}{*}{0.44} \\
\hline & Resistant & $22(61.1 \%)$ & $14(38.9 \%)$ & \\
\hline \multirow{2}{*}{ Amphotericin B } & Susceptible & $51(53.7 \%)$ & $44(46.3 \%)$ & \multirow{2}{*}{0.04} \\
\hline & Resistant & $5(100 \%)$ & $0(0 \%)$ & \\
\hline
\end{tabular}

higher in non-albicans candida species ${ }^{14,16}$. Therefore, it is essential to identify the causative pathogen for VVC to provide sufficient treatment and prevent recurrence. For non-albicans species, amphotericin B is a more efficient drug of choice comparing to itraconazole and fluconazole, which are commonly used antifungal agents in clinical practice16. Our study results also support this literature.

In order to diagnose VVC, although culture is not a required work up, it plays an important role to identify non-albicans strains for effective management of disease in persistent or recurrent infections ${ }^{1}$. Nonalbicans strains which colonize in vaginal flora after the loss of lactobacilli due to previous antibiotic use are one of the criteria to describe complicated infections ${ }^{18}$. As the non-empirical pathogen aided drug therapy is going to decrease recurrence of these complicated infections, identifying the suspected strain for resistant infections after antibiotic use is a useful option to decrease infection frequency.

Correlation between previous antibiotic use and VVC prevalence is essential to understand expectant vaginal yeast infection and choice of treatment. The literature supports that antibiotic use is increasing the VVC in patients with vaginitis symptoms ${ }^{19}$. There are not enough studies in the literature that compares which antibiotic groups are more suspicious for VVC. Only a few data searched a specific antibiotic group about VVC frequency, it is suggested that cephalosporins carry the risk for further VVC, and norfloxacin use for urinary tract infection is not a predisposing factor for $\mathrm{VVC}^{20,21}$. The correlation between previous antibiotic use and antifungal drug resistance development by Candida species is an unenlightened topic.

Our study results support that the effect of previous antibiotic use on antifungal resistance in candida strains is not statistically significant. At that point, recurrent candida infections after antibiotic use may be related to a different mechanism other than antifungal drug resistance, such as changes in vaginal flora with a decrease in lactobacilli amount.

Limitations of this study include an insufficient number of patients, treating patients only with antifungal drugs and not to add lactobacilli increasing agents to treat, and having limited information of patients about risk factors of recurrent VVC such as pregnancy, diabetes mellitus, or immunosuppression. 
Since resistance to voriconazole, fluconazole, and amphotericin B was more frequent in the non-albicans group, physicians should suspect from non-albicans strains for treatment-resistant VVC cases. Previous antibiotic use did not affect the fluconazole and voriconazole resistance of both candida albicans and non-albicans strains. Recurrent infections that do not respond fluconazole or voriconazole treatment may be due to a different mechanism other than antifungal resistance of Candida species. Decreased amount of lactobacilli in vaginal flora might be the reason for recurrent VVC.

\section{References}

1. Workowski KA, Bolan GA. Centers for disease, C. \& prevention. Sexually transmitted diseases treatment guidelines, 2015. MMWR Recomm Rep, 2015, 64, 1-137.

2. Yenidunya $S$, Hatlas $H$, Bayrak R. To determine of the prevalence of Bacterial Vaginosis, Candida sp, mixed infections (Bacterial Vaginosis +Candida sp), Trichomonas Vaginalis, Actinomyces sp in Turkish women from Ankara, Turkey. Ginekol Pol 2012;83(10)

3. Jeanmonod R, \& Jeanmonod D. Candidiasis, Vaginal (Vulvovaginal Candidiasis). StatPearls. Treasure Island (FL)2017.

4. Grigoriou O, Baka S, Makrakis E, Hassiakos D, Kapparos G, Kouskouni E. Prevalence of clinical vaginal candidiasis in a university hospital and possible risk factors. Eur J Obstet Gynecol Reprod Biol, 2006, 126, 121-5.

5. A, V. S. \& E, A. K. Vaginal Protection by $\mathrm{H} 2 \mathrm{O} 2$-Producing Lactobacilli. Jundishapur J Microbiol, 2015, 8, e22913.

6. Bertuccini L, Russo R, Iosi F, Superti F. Effects of Lactobacillus rhamnosus and Lactobacillus acidophilus on bacterial vaginal pathogens. Int J Immunopathol Pharmacol, 2017, 30, 163-167.

7. Melkumyan AR, Priputnevich TV, Ankirskaya AS, Murav'eva VV, LUBASOVSKAYA LA. Effects of antibiotic treatment on the lactobacillus composition of vaginal microbiota. Bull Exp Biol Med, 2015, 158, 766-8.

8. Wilton L, Kollarova M, Heeley E, Shakir S. Relative risk of vaginal candidiasis after use of antibiotics compared with antidepressants in women: postmarketing surveillance in England. Drug Saf 2003;26(8) 589.
9. Beigi RH, Meyn LA, Moore DM, Krohn MA, Hillier SL. Vaginal yeast colonization in nonpregnant women: a longitudinal study. Obstet Gynecol, 2004, 104, 926-30.

10. Nyirjesy P. Management of persistent vaginitis. Obstet Gynecol, 2014, 124, 1135-46.

11. Bliss JM, Basavegowda KP, Watson WJ, Sheikh AU, Ryan RM. Vertical and horizontal transmission of Candida albicans in very low birth weight infants using DNA fingerprinting techniques. Pediatr Infect Dis J, 2008, 27, 231-5.

12. Zisova LG, Chokoeva AA, Amaliev GI, Petleshkova PV, MitevaKatrandzhieva Tcapital EMC, Krasteva MB et al. Vulvovaginal Candidiasis in Pregnant Women and its Importance for Candida Colonization of Newborns. Folia Med (Plovdiv), 2016, 58, 108-14.

13. Wiederhold NP. Antifungal resistance: current trends and future strategies to combat. Infect Drug Resist, 2017, 10, 249-259.

14. Macura $A B$, Skóra $M$. Fungi isolated from the vagina and their susceptibility to antifungals. Ginekol Pol 2012;83(6).

15. Mohanty S, Xess I, Hasan F, Kapil A, Mittal S, Tolosa JE. Prevalence \& susceptibility to fluconazole of Candida species causing vulvovaginitis. Indian J Med Res, 2007, 126, 216-9.

16. Mutua F, Revathi G, Machoki JM. Species distribution and antifungal sensitivity patterns of vaginal yeasts. East Afr Med J, 2010, 87, 156-62.

17. Ozcan SK, Budak F, Yucesoy G, Susever S, Willke A. Prevalence, susceptibility profile and proteinase production of yeasts causing vulvovaginitis in Turkish women. APMIS, 2006, 114, 139-45.

18. Sobel JD, Faro S, Force RW, Foxman B, Ledger WJ, Nyirjesy PR et al. Vulvovaginal candidiasis: epidemiologic, diagnostic, and therapeutic considerations. Am J Obstet Gynecol, 1998, 178, 203-11.

19. Pirotta MV, Garland SM. Genital Candida species detected in samples from women in Melbourne, Australia, before and after treatment with antibiotics. J Clin Microbiol, 2006, 44, 3213-7.

20. Macdonald TM, Beardon PH, Mcgilchrist MM, Duncan ID, Mckendrick AD, Mcdevitt DG. The risks of symptomatic vaginal candidiasis after oral antibiotic therapy. QJ Med, 1993, $86,419-24$.

21. Rocha RM, Zanni PC, De Souza Bonfim-Mendonca P, Gimenes F, Alczuk SS, Svidzinski TI et al. Effect of norfloxacin therapy for acute, uncomplicated lower urinary tract infection on vaginal Candida prevalence. Int Urogynecol J, 2016, 27, 773-80. 